\title{
JUSTICE AND LIBERTY IN HEGEL
}

\author{
JUSTIÇA E LIBERDADE EM HEGEL
}

THADEU WEBER ${ }^{l}$

(PUCRS, Brazil)

\begin{abstract}
This paper aims to make explicit the concept of justice in Hegel's Philosophy of Right. It bounds it to the idea of liberty in its different ways of determination. It starts from the notion of person of right and indicates the fundamental rights that derive from the expression of this legal capacity. It highlights the right of necessity as a right to make an exception in favor of itself aiming the actualization of justice. It shows how, through the Law, in civil society, it happens the administration of justice.

Keywords: Justice. Liberty. Fundamental rights. Civil society. State.
\end{abstract}

\section{Introduction}

By constructing principles of justice to be applied to society's basic structure, Rawls understood Hegel's critique to the excessive formalism in Kantian moral and the consequent valorization of "ethicity" (Sittlichkeit) and its social institutions. Recovering them is fundamental for a theory of justice, since they are the place where liberty, the proper content of justice, is actualized.

Liberty is the guiding and founding principle of Hegel's Philosophy of Right. To talk about justice means to point its forms of actualization. More specifically, to make justice means to assure liberty on its instances of mediation of juridical and social structures. The system of right is, this way, "the kingdom of actualized liberty" (Rph $\S 4){ }^{2}$

On this configuration - although the whole Philosophy of Right could be considered a theory of justice - two moments are especially important in the referred text: one refers to "abstract right" and the other to civil society. Those are two levels on which Hegel approaches directly to the justice topic, bound to the idea of liberty, as Concept of Right. The State could be referred to as the third moment, considering it is the actualization of the "ethical substantiality." However, there is no explicit reference in it to the concept of justice, since this is par excellence an attribution of civil society, considered as the "external State." It is fundamental to demonstrate how, at the level of ethicity, individual self-realization is 
assured through the effectuation of rights, duties, and liberties on social institutions. For justice is, fundamentally, social justice.

We need to bear in mind that Hegel's Philosophy of Right, accordingly to what is announced in its first paragraph, aims to expose the underlying thread of the internal logics of juridical and social structures while actualizations of the Concept of Right. Hegel rebuilds the rational course of the internal logic of the determinations of the Idea of Liberty. The Science of Right, on its turn, is a part of Philosophy, insofar as it seeks on the latter its own guiding principle. Hegel proposes a "philosophical science of right," which has as object the "idea of right," i.e., the philosophical idea of liberty. In this manner, to expose the internal structures of the right means to show the unfolding of the Concept of Right while actualization of the idea of liberty. ${ }^{3}$ Justice permeates all of these configurations. It actualizes itself through the actualization of liberty. This is the "content of the idea of justice." (Salgado, 1996, p. 467) On the abstract right, it is discussed at the level of individual liberties; on morality, as the right of subjectivity; on ethicity, it is focused on the subject-society-State relation. The challenge is to show how it is possible to conciliate justice and liberty on these instances of mediation. Put in other words: how to concretize liberty on juridical and social structures within reasonable standards of justice? How to conciliate individual interests and liberties with collective ones? The guarantee of this actualization, ultimately, happens at the level of ethicity. However, isn't it proper of the Concept's dialectical movement to weaken or even to annihilate individual wills in favor of the affirmation of the substantial will? Isn't liberty, ultimately, recognition of necessity? Isn't there a subordination of individuals' liberty to the ethical authority of the State? And isn't the standard of justice justified on that basis? The purpose here is to refuse this suspicion and demonstrate that Hegel's theory of justice is founded on the principle of individual liberty equally mediated by the liberty of all. Self-determination and reciprocal recognition are key categories here.

\section{Justice and immediate determinations of liberty}

The exposition of the idea of justice on the actualization of the idea of liberty on the "abstract right," as the first figure of the Philosophy of Right, starts from a fundamental presupposition: the person of right. Person is the subject conscious of itself; it implies "legal capacity." To be person means to be subject of subjective rights. It is the most abstract and indeterminate manifestation and, as such, it establishes the fundamental equality of all human 
beings. It indicates that the man is worth as man. That they should be recognized and respected as free and equal. Hence the categorical statement: "Be a person and respect others as persons” (Rph §36). This doesn't imply, though, an equal distribution of goods, since "wealth depends on one’s diligence” (Rph §49). Equality refers to the fact of being persons; it regards its legal capacity, even if potential. For instance, it means that every person should have property, in order to satisfy their material basic needs and the expression of their will. However, justice does not require that everyone's properties be equal. Hegel argues: "In relation to external things, the rational aspect is that I possess property; the particular aspect, however, includes subjective ends, needs, wills, talents, external circumstances, etc." (Rph $\S 49)$. The emphasis is on the distinction between what is necessary and what is contingent for the development of the Concept of Right. The question is qualitative, not quantitative. It becomes an important criterion for the effectuation of justice. "What and how much I possess is contingent as far as right is concerned" ( $\mathrm{Rph} \S 49)$.

This notion of person of rights underlies the whole process of actualization of the idea of liberty on the juridical and social structures and, therefore, of the idea of justice as well. In this way, it needs to be set out as the expression of liberty. To be person means to be inviolable before justice and liberty. It means to be respected and protected. Honneth argues that the determination of the free will on the "right" is the "core of a theory of justice that seeks to guarantee the intersubjective conditions of individual self-actualization" (Honneth, 2007, p.52). The satisfaction of these conditions is a demand imposed to ethicity, as we shall see.

The first juridical form of a person to concretize its free will is the possession, whence derives the fundamental right of use. It is the most immediate form by which a person relates with the world; as effectuation of its legal capacity it is the "external sphere of its freedom" (Rph §41). However, this right needs to be recognized in order to become a right of property, which, in its turn, includes one more right: the right of exchange. This recognition only happens through a contract. This is the mutual recognition of rights and duties. It shows that Hegel's idea of justice, even on the level of immediate determinations, is based on selfdetermination and reciprocal recognition.

The exigency of the contract is due in order to guarantee the property and the possible transference of it to another person. It is established at the level on interpersonal wills. The most important here is the free will of the parties involved, not the thing or its attributes. It is the will what legitimates the contract. The recognition of property is the recognition of the 
free will. It is a mutual concession of rights and duties. Bound to this idea of free will is the "idea of individual autonomy or self-determination" (Honneth, 2007, p. 57).

Contracts are made between "immediately independent persons" through the manifestation of each one's individual wills. This manifestation is what legitimates the contract. Its origins are in the "immediate will" (Willkür); there is no social mediation yet. That is why contracts are at the level of the abstract right. Persons express their immediate and, as such, contingent wills. "The particularity of the will for itself is arbitrariness and contingency" (Rph $\S 81)$. It means that these may not coincide with the "will existing in itself" the "universal will," i.e., on the level of abstract right, it can not be hindered the possibility of one imposing its own will over the other's, repressing it. Whence injustice arises. Disregarding the pact is unjust, for it is the expression of free wills. The contractual relation happens between "immediate persons, in which it is purely contingent whether their particular wills are in conformity with the will which has being in itself' (Rph §81). While particular, the will is different from the "universal will" and, according to Hegel, "if its attitude and volition are characterized by arbitrariness and contingency, it enters into opposition to that is right in itself, this is unrightful (das Unrecht)" (Rph § 81). The origin of the unjust lies on the immediacy of the will, which is contingent. We cannot forget that the immediate will is a moment of liberty. That is why the just-unjust relation presupposes free acts. It is important to highlight that a contract or another agreement encompasses the "right to reclaim its execution." However, that depends, again, on the particular will, which, by its turn, may act contrary to the right as such. This is where injustice lies. Hegel argues that the will "needs to be purified from its immediacy" (Rph §81). It means that it should pass by the process of mediation and recognition; the will needs to free itself from this "suffering from indeterminacy." Well, the wills are not eliminated through this process, but, through mediation, they are overcome and conserved in a higher level. To free itself from indeterminacy is to enter the dialectical movement of mediations and determinations.

At this first level of actualization of liberty, justice, and its effectuation, is bound to interpersonal relations and, therefore, to individual immediate wills. Hence the need for instances of regulation and guarantee on other levels of mediation. In the contract, the parties "still maintain their particular will." This moment is necessary, but not sufficient for actualizing liberty and justice. We are at the level of the immediate will, and its exercise is subject to injustice. Other instances of mediation and determination are imposed. We need to get rid of the indeterminacy of the immediate wills and search for the ethical substantiality 
through the mediation on the social institutions, for it is through them that liberty and justice are actualized.

It is important to notice that the unjust is a consequence of the free will. The damage is provoked by the conflict originated through the confrontation between a particular will and the universal will, represented by the right in itself. The cause of this confrontation is a caprice of the particular immediate will that is completely vulnerable. As actualization of the idea of liberty in its most immediate figure, the contract is the product of two contingent wills, and, as such, can be terminated at any time. A contact between contingent wills has by its very nature the possibility of being terminated. Besides that, these wills may not necessarily coincide with the universal will. This, says Hegel, is due to the own logic of the Concept. The particular will can impose its individual right. Although it may seem that there is an excessive emphasis on the downside of the contingent particular wills, we have to notice that it is from the same wills that creative acts arise, capable of modifying the process of interiorization of the necessary structures of Right. It is the passage from indeterminacy to determinacy, mediated by the individuals' free wills.

At the level of the abstract right, the central problem is about a contractual relation between two wills that are still unable to respect themselves mutually, for they have not yet mediated their individual interests. They are still bound to their immediacy. At this level, the Concept is considered before its process of determination and its effectuation. The wills have not yet been overcome and conserved on the universal will, the right in itself. The possibility of injustices emerges from this relativity of the abstract right. The injustice is a mere semblance of what "must be," the right in itself (the essence). "A semblance is existence inappropriate to the essence" ( $\mathrm{Rph} \S 82)$. The injustice is a semblance that must disappear, giving rise to the right as something determinate and valid. The relation between the right in itself and the particular will is the relation between the essence and its appearing. The essence is the necessary and the true; the semblance, if not adequate to the essence, is injustice. This is an indeterminacy from which it is needed to escape.

For Hegel, there are three levels of this semblance of right, while particular, before the "universality of its being in itself" (Rph §83). Put in other words, there are three levels of violation (three degrees of violation intensity) that a particular will, subject to the immediate will, may cause:

a) The good faith injustice 
At this first level, the will of one of the parties is injured on an involuntary way, for the unjust is taken as just. The semblance is taken as essence. The violation provoked is not voluntary. The possession and the contract are the "juridical bases." It may happen, however, that regarding the same thing, different people reclaim rights. Each one of them may consider to have property over the same thing, taking as ground "their particular juridical basis." This is where the juridical conflicts originate. At this first level, regarding the conflicts, there is "the recognition of right as the universal and deciding factor, so that the thing may belong to the person who has a right to it" (Rph §85). The good faith injustice denies only the particular will, but respects the universal right. This is the least harmful violation. There is the recognition of right. The person wants and must have what rightfully belongs to them. What happens is that, at this first level of injustice, the right is mistaken for the contingent particular will.

\section{b) The deception}

This violation has a higher intensity. In this case, "the unjust is not a semblance from the point of view of right in itself; instead, I create a semblance in order to deceive another person. When I deceive someone, right is for me a semblance” (Rph §83). In this case I am unjust. A misleading is provoked with the purpose of entering in a contract. Information is withheld by the seller in order to sell a good.

\section{c) The violence and the crime}

This is the most intense form of harming the other's will. The perpetrator wants to be unjust. He disrespects both the right in itself and how it appears to him (cf. Rph §90). He does not recognize the other's right, for his intention is to harm someone's liberty. The violation of a contract, the harm of juridical duties towards the family and the State are examples of violence. A. Valcárcel makes a remark about the crime as a form of violence: "Crime is violence against the right, and, for restoring the balance, this violence has to be nullified by the violence that rights brings implicitly. This violence, moreover, only expresses itself in this case" (Valcárcel, 1988, p. 338). That is why the right is authorized to coerce. The penalty applied to the perpetrator is a way of reestablishing the pact and reverting the harm caused. The penalty is not an act of revenge from society, but must be understood as a way of making justice to the evildoers. It seeks to restore the constituted juridical order. The crime is objective, and, as such, must be nullified through the application of the penalty. It is not something irrational, but "the expression of a free will that freely opposes to the right" (Valcárcel, 1988, p. 342). That is why the perpetrator can be punished. 
In these three levels of violation, the free will of the acting subjects is presupposed. Hence their responsibility. This collision of wills demands an instance on which they can be administered. This is the role of the right as law. And this brings us to civil society.

\section{The right of emergency}

From the right of morality point of view, it is appropriate to highlight Hegel's critique to the formalism of Kantian moral, especially by the "right of emergency" (Notrecht). For the philosopher from Königsberg, recognizing the universal validity of the moral law and at the same time making an exception in one's own favor is to incur in a contradiction. There is a defense of the a priori validity of the law, regardless of the circumstances. In contrast to this, Hegel argues for the right of making an exception in one's favor in case of extreme necessity. What is at stake is a threat to life. It is a right, not a concession. It means that "the necessity of the immediate present can justify an unjust action, because its omission would in turn involve committing an injustice-indeed the ultimate injustice, namely the total negation of the existence of freedom" (Rph §127). The emergency situations do not invalidate the law, but show the level of its relativity regarding justice. The defense of life justifies any action against the law. This right of emergency implies "the benefit of competence, whereby a debtor is permitted to retain his tools, agricultural implements, clothes, and in general as much of his resources - i.e. of the property of his creditors - as is deemed necessary to support him, even in his accustomed station in society” (Rph, §127).

The right of emergency is, in fact, a resource against injustice or unjust consequences resulting from the application of the law. The conflict between rights in their effective exercise demands pondering and hierarchizing. The guarantee and the protection of life justify any exception to the law. Such as the right states, the emergency is current and demands a decision in the immediate present, for the future wholly depends on contingency. This is a heavy blow to the formalism of Kantian moral, since he admits no exceptions. Kant does not recognize the right of equity and the right of necessity, even though he refers to them as presupposed rights. The background of the exercise of this right is the distinction between rules and principles. When the application of the former brings unjust consequences, one should invoke the principles, which may not even be written. The same applies to the precedent rule: similar cases may not have similar approach if the consequences of it show themselves unjust. The judge only applies an unjust rule if he wants to. Of course, the right of 
emergency refers to situations of serious threat to life. It is, in fact, a right that complements the right of morality, i.e., the right to know and will, while conditions of subjective responsibility. The issuance of a moral judgment cannot ignore these rights or avoid assessing them.

It is yet important to highlight-regarding the conditions of subjective responsibility, discussed by Hegel in the figure of morality - the right of intention. To know and to will to do are conditions for the issuance of a moral judgment. However, "an intention to promote my welfare and that of others [...] cannot justify an action which is unjust" (Rph §126). An unjust action, here, is an action against the right. It shows that in the logic of realization of the principle of liberty, morality and ethicity overcome and conserve the rights guaranteed by private law (abstract right). Morality does not oppose to the abstract right, but states its insufficiency. Thus, it is demonstrated the incompleteness of Kantian moral. On the ethicity, the individual frees himself from the suffering from indeterminacy: the abstract right and the morality.

\section{Justice and civil society}

To talk about civil society and family is to talk about the institutions of social mediation of the free will. The instances of mediation of the idea of liberty find in ethicitythird figure of the Philosophy of Right - their complete concretion and realization. For Honneth, one of the minimum conditions the ethicity sphere must fulfill in order to free itself from the "suffering from indeterminacy" is "to make available accessible possibilities of individual realization, self-actualization, whose use can be experienced by each individual subject as practical actualization of their liberty" (Honneth, 2007, p. 106). Since ethicity deals with the social mediation of the free will, the individual realization encompasses "reciprocal recognition." The intersubjective actions of the ethical sphere "express determinate forms of reciprocal recognition" (Honneth, 2007, p. 109) and individual actualization.

Within the ethical sphere, the administration of justice lies in the civil society. The judiciary is, therefore, a power of civil society, not of the State. It shows that the civil society must assume the guarantee of its conditions of possibility. In this second moment of the Philosophy of Right, justice assumes a fundamental role. Civil society (corporations) constitutes, along with family, an ethical base of the State. Two principles comprise this base: the "concrete person"-while particularity of interests - and the social context. Bearing in 
mind that civil society is a place of conflicts, which result from the satisfaction of needs, the challenge is how to conciliate particular interests with collective ones. Hegel defines civil society as "the field of conflict in which the private interest of each individual comes up against that of everyone else" (Rph, §289). The search for the satisfaction of personal interests many times superposes the collective ones. Corporations are associations of individuals motivated by a "system of needs" that requires the mediation of the others' wills for its own satisfaction. Ethicity must fulfill the intersubjective requirement and, through this, actualize justice. Regarding the administration of justice, Hegel focus - among other things — on the safeguard of property and personality by justice, for it is the instance that seeks to assure reciprocity (reciprocal recognition) on the satisfaction of needs. It is the right exercised.

Hegel, in paragraph 209, insists on a basic presupposition: "a human being counts as such because he is a human being, not because he is a Jew, Catholic, Protestant, German or Italian." This is the common base on which Hegel discusses the themes of justice and liberty. From then on, to make justice explicit on civil society means to treat the right as law before which everyone is equal. "What is right in itself is posited in its objective existence-i.e. determined by thought for consciousness and known as what is right and valid - it becomes law” (Rph §211). The right, in its objective reality, must meet two basic conditions: being known and being valid, and therefore, as Hegel states, "becoming known as universally valid" (Rph §210). This is the role assumed by the law. It becomes known as what is valid and what is just. For administering justice, on the level of civil society, the criterion is the law. However, this is not yet the actualization of the Concept.

When transformed into law, the right reaches its "true determination" and acquires the character of obligatoriness. It then defines positively what is just, which does not mean it is conceptually just. However, it is important to underline that contingency accompanies all the moments of determination of the idea of liberty. D'Hondt states: “The dialectical Hegel cannot conceive an absolute negation of the contingent" (D'hondt, 1966, p. 207). It means that the determination of the right as law may encompass "the contingency of caprice and other particularities," which, on its turn, may not coincide with the right in itself. What is "of right" is given us by the law, but it does not mean that the law is always in accordance with the Concept of Right (what must be). Therefore, justice is given by the Right in inself, not necessarily by the law. Since the law is a determination of the Concept, and since there may be contingency in this determination, the law may distance itself from the Concept. With the "administration of justice," Hegel wants to render explicit the application of the law to the 
singular case. It implies the knowing the case in its "immediate individuality" and the submission to the law in order to restitute the right (cf. Rph §225). What is in accordance to the positive law only tells us what is lawful. In that way, "the determination by the concept imposes only a general limit within which variations are also possible" (Rph §214). The positive law states what is legal or illegal, not what is just.

The actualization of justice goes through different levels of mediation of will on the ethicity institutions. On the level of civil society, the guidelines are the law. On State, the Concept. The determination of the Concept on civil society is the law. "The fact that right is posited also makes it applicable to the individual case" (Rph §214). The "pure positiveness of the law" is on its immediate application. The difficulty in this application of the law to the individual case is to reach justice (originating in the concept). Put in other words: how does one know if a penalty is just, considering, on the one hand, a determination from the Concept of Right, and, on the other hand, the contingent character of the individual case?

We can resort to a clarifying excerpt from the Philosophy of Right:

It is impossible to determine by reason, or to decide by applying a determination derived from the concept, whether the just penalty for an offense is corporal punishment of forty lashes or thirty-nine [...] or imprisonment for a year and one, two, or three days [...]. And yet an injustice is done if there is even one lash too many (zuviel) [...] or one week or one day in prison too many or too few (zuwenig)" (Rph §214).

What is a lash too much? Who defines it? It is what goes beyond the law or the Concept? Hegel says, here, that it is not possible to quantify a penalty starting from the Concept (what should be). It has to be done by the law, which always implies some arbitrariness. But the law and the Right are not the same? Although it is difficult to determine what is just when applying the law, one needs to make decisions, within some limits, even if they have an arbitrary character. Administer the injustice of an extra day in prison may indicate two things: On the one hand, for determining the penalty according to the law, one needs to apply the law. It is contingent that a penalty of two years of prison be determined to a certain crime, but it is a necessary contingency; the law says the Right, it says what should be done. One day more or less than the established is unjust. Here is a concept of formal justice. On the other hand, the just is not defined by the law, but by the Concept of Right. Here the too many or too few is what goes beyond what should or should not be. Laws, albeit having ethic@- Florianópolis v.13,n.1, p. 188 -203,Jun. 2014. 
the role of actualizing the concept, never fully reach it. It is the Right as law. The law is the Right put in its objective existence. Says Hegel: "it is the reason itself which recognizes that contingency, contradiction, and semblance have their (albeit limited) sphere and right, and it does not attempt to reduce such contradictions to a just equivalence" (Rph §214). The fundamental point is to actualize the Concept of Right as law, even if the latter does not fully actualize the former. For that, one needs to determine and decide within limits. However, the Concept (what must be), elaborated by reason, is the idea that, at the same time, regulates and constitutes it. There is still one ambiguity left: If it is the Concept what defines the just, how to affirm that what the law states is just?

It is important to underline the contingent character of the administration of justice, which is acknowledged by reason. That is why the law must be a "general determination" to be applied to individual cases. The quantity of a penalty has always an arbitrary dimension. It cannot adapt itself to the Concept. But a decision must be made even though within numerous options. Hence the contingence of the right as law. That is why Hegel says: "this contingency is itself necessary" (Rph §214). Whence derives the impossibility of reaching the completeness of a legislation. "There is essentially one aspect of law and the administration of justice which is subject to contingency” (Rph §214). Well, this is proper of a normative science. Without contingency there is no liberty. For this reason, it should be recognized as having its right, albeit limited. The Concept of Right, i.e., the idea of liberty, when actualized, determines itself on the contingent particularity. Hence the difficulty of actualizing justice. For all of those reasons, the law must be a general determination to be applied to individual situations and cases. Hence the role of legal hermeneutics.

It is important to highlight that the obligatoriness of obeying the law demands, most of all, that they be known by all, i.e., publicity is the condition for obligatoriness. Besides that, they need to be well specified in order to be applied to particular cases.

\section{Justice and State}

The civil society is unable to solve their own conflicts. These antagonisms, originated in the satisfaction of a "system of needs" of individuals and groups, require the vigilance of other instance of mediation: the State. Is the State able to fully actualize justice through the guarantee and protection of liberty, i.e., of individual autonomy and selfdetermination? Would it sacrifice individual and collective interests and liberties in order to 
assure the substantial, or the fundamental rights and liberties are put aside and preserved on the substantial? What is exactly the limit of the State's liberty? Doesn't one take the risk of justifying a totalitarian State, regarding the subordination of the "rights of individual liberty" to the State's authority? This suspicion is raised against Hegel. ${ }^{4}$

The answer to these questions demonstrates the level of justice possible within the Hegelian State. Now, affirmation implies negation. To actualize the idea of liberty requires the actualization of justice within the proper limits of mediation of the wills. To regulate institutions does not mean to eliminate or to weaken liberty, but to make them feasible intersubjectively. The different forms of social mediation of the free will that constitute the ethicity sphere are nothing but different ways of reciprocal recognition. On Honneth's words: "The ethicity sphere must encompass a series of intersubjective actions on which individuals may find both individual actualization and reciprocal recognition" (Honneth, 2007, p. 110). Family and corporations are places for it to happen. The State is the last instance. The actualization of justice has a difficult course between the "immediate ethical relation," proper of the family, and the State's ethical substantiality. This substantiality is built through the process of mediation and recognition of the individual's free wills. That is why the ethical is an universal way of acting." The mediated and recognized immediacy is then substantialized.

Hegel refers to the State as the "actuality of the substantial will" on which the "particular self-consciousness [...] has been raised to its universality" (Rph §258). He argues that on this substantial unity, "liberty reaches its supreme right" and that the individual has the "supreme duty of being member of the State." Here we are before the most absolute justification of the State. It is not possible to actualize liberty and justice outside it. Albeit prior to civil society on a historical point of view, on the logics of the actualization of the idea of liberty the State comes after it. This emphasizes the need for an instance that administers the conflicts originated on its ethical bases, especially the corporations of civil society.

The challenge now is to demonstrate until what level the State effectively assures the actualization of liberty, and, consequently, of justice. In paragraph 260 of the Philosophy of Right, Hegel states that "the State is the effective reality of the actualized liberty." What does it mean? How to assure particular interests among social institutions? How to assure individual actualization and self-determination among reciprocity? Hegel dedicates some paragraphs to demonstrate that in order to liberty to be actualized, particular and collective interests must be conciliated. The actualization of individuality is assured through the exercise of "a universal activity” (Rph §255). In paragraph 260, Hegel says: 
Concrete freedom requires that personal individuality and its particular interests should reach their full development and gain recognition of their right for itself (within the system of the family and of civil society), and also that they should, on the one hand, pass over of their own accord into the interest of the universal, and on the other, knowingly and willingly acknowledge this universal interest even as their own substantial spirit, and actively pursue it as their ultimate end (Rph §260).

Concrete liberty, therefore, means the actualization of particular interests in the universality; while conciliated, overcome and conserved (or sublated), but not eliminated. Individual actualization implies reciprocal recognition, having, on this way, "an universal life" (Rph §258). Honneth is right when affirms that recognition means "a reciprocal affirmation without any coercion from certain personality traits that relate to each mode of social interaction" (Honneth, 2007, p. 108). The individual only deserves to be recognized if their behavior towards the others can be universally valid. That is why, on the level of ethicity, the individual acts on an universal manner. Intersubjective actions are the expression of reciprocal recognition.

The state is just when it develops and recognizes the rights of their citizens, but at the same time points the "general interest" as limit to their exercise. This shows the mutual dependency between the particular and the universal. The latter is not actualized without the "interest, knowledge, and volition of the particular," neither is the individual actualized as a private person without "directing their will to a universal end" (Rph §260). Concrete liberty requires the recognition of both particularity within universality and universality within particularity. The universality guarantees the actualization of the particularity, since the latter has the former as its ultimate end. That is why family and civil society are the State's ethical bases. The individual only makes itself sure of its individuality, in its particularity and reciprocity, as member (Mitglied) of a family and a corporation. It is important that the individual can find within the State his own individual interests - of course, mediated and recognized. The State actualizes justice inasmuch as it assures fundamental rights and liberties. Hegel is clear when arguing that the role of the State is "to protect and secure the life, property, and immediate will of everyone" (Rph \$270). The individual's particularity is only assured on the three levels of ethicity — family, civil society and State - for these are the instances on which it is mediated and universalized. "The individual subject is included in the 
'State' when it be able to rationally form his 'abilities', dispositions and talents, so that they can be utilized for the universal good" (Honneth, 2007, p. 122).

In paragraph 261, Hegel recovers the paragraph 155 and reiterates the identity between rights and duties at the level of the "ethical State." The duties towards the substantial are, at the same time, the existence of the particular liberty, i.e., "duty and right are united within the State in one and the same relation" (Rph §261). An ethically correct State, i.e., a just State, presupposes equality between rights and duties. If the slave has no rights, he also must have no duties. Thus, slavery is, by definition, unjust. It is the most serious violation of the human dignity. It transgresses the principle "be a person and respect others as persons," presupposition that defines the "person of right." Hegel emphasizes the importance of the particularity moment and its satisfaction. "In the process of fulfilling his duty, the individual must somehow attain his own interest and satisfaction or settle his own account, and from his situation within the State, a right must accrue to him whereby the universal cause becomes his own particular cause” (Rph §261). The particular interests, thus, must be overcome and conserved on the substantial. The latter is the result of the mediation of the former ones. What is demanded as a duty from the State is equally a right to individuality. This State is just and ethically correct.

\section{Final considerations}

The concept of justice is directly bound to the effectuation of the fundamental rights stipulated by the "abstract right." While actualization of the liberty, they must be protected and assured as expression of the person of right's legal capacity.

Inasmuch as it deals with the determinations and actualizations of the principle of liberty as a historical conquest, the Philosophy of Right can be considered a theory of justice. This is made clear by the process of overcoming and conserving the individual rights in this dialectical movement of actualization. Self-determination and reciprocal recognition underlie these mediations. The suspicion that the Philosophy of Right brings along "anti-democratic consequences" in the sense that "rights of individual liberty" would be "subordinate to the State's ethical authority," is definitely weakened (Honneth, 2007, p. 48). ${ }^{5}$

The right of emergency is the landmark of the dialogue between Kant and Hegel. It is essential to demonstrate Hegel's advance regarding the actualization of justice in situations of extreme necessity. The guarantee of the life and everything it implies (e.g. material basic 
needs) is the basic principle of any institution that aims to assure the minimum standards of justice.

Since the State is the instance of actualization of the citizen's liberties, it is its duty to assure the protection of fundamental rights and liberties, whether individual or social ones. In doing so, it will guarantee justice. The contribution of Hegel was crucial in the sense of pointing the place of the actualization of liberty within the dialectical movement of social institutions. This presupposes, obviously, that the Concept of Right-whose object is the idea of liberty—dialectically binds Right, Morality and Ethicity.

\footnotetext{
Notes:

${ }^{1}$ Thadeu Weber is graduated, has a Master's degree and a $\mathrm{PhD}$ in Philosophy. He is full-time professor of Philosophy and Right at the Pontifical Catholic University of Rio Grande do Sul, Porto Alegre, Brazil. His research focuses are on Theories of Justice, Ethics and Political Philosophy. His main works are: "Hegel: Liberdade Estado e História"; "Ética e Filosofia Política: Hegel e o Formalismo Kantiano"; and "Ética e Filosofia do Direito: Autonomia e Dignidade da Pessoa Humana”. E-mail: weberth@pucrs.br

${ }^{2}$ Rph stands for Rechtsphilosphie (Hegel, Grundlinien der Philosophie des Rechts).

${ }^{3}$ Regarding this subject, see Thadeu Weber, Hegel: Liberdade, Estado e História (Petrópolis: Vozes, 1993), chapter 2 .

${ }^{4}$ Cf. Axel Honneth, Sofrimento de indeterminação, 48. See also Karl Popper, A sociedade aberta e seus inimigos (São Paulo: Itatiaia, 1974), 37.

${ }^{5}$ The author presents this suspicion as a prejudice against Hegel's Philosophy of Right.
} 


\section{References}

D’HONDT, Jacques. Hegel, Filósofo de la Historia Viviente. Buenos Aires: Amorrortu Editores, 1966.

HEGEL, Georg W. F. Grundlinien der Philosophie des Rechts. Frankfurt am Main: Suhrkamp, 1986.

HONNETH, Axel. Sofrimento de indeterminação: uma atualização da Filosofia do Direito de Hegel. São Paulo: Editora Singular, 2007.

SALGADO, Joaquim Carlos. A idéia da justiça em Hegel. São Paulo: Edições Loyola, 1996.

VALCÁRCEL, Amelia. Hegel y la Ética. Barcelona: Anthropos, 1988.

WEBER, Thadeu. Hegel: Liberdade, Estado e História. Petrópolis: Vozes, 1993. 